\title{
Platelet count and platelet indices in women with preeclampsia
}

This article was published in the following Dove Press journal:

Vascular Health and Risk Management

21 November 2016

Number of times this article has been viewed

\author{
Muneera A AISheeha' \\ Rafi S Alaboudi' \\ Mohammad A Alghasham' \\ Javed $|q b a|^{2}$ \\ Ishag Adam' \\ 'Department of Obstetrics and \\ Gynaecology, College of Medicine, \\ Qassim University, Buriadah, \\ ${ }^{2}$ Department of Obstetrics \\ and Gynecology, Maternity and \\ Children's Hospital, Qassim, \\ Kingdom of Saudi Arabia
}

Background: Although the exact pathophysiology of preeclampsia is not completely understood, the utility of different platelets indices can be utilized to predict preeclampsia.

Objective: To compare platelet indices, namely platelet count (PC), mean platelet volume (MPV), platelet distribution width (PDW), and PC to MPV ratio in women with preeclampsia compared with healthy controls.

Setting: Qassim Hospital, Kingdom of Saudi Arabia.

Design: A case-control study. Sixty preeclamptic women were the cases and an equal number of healthy pregnant women were the controls.

Results: There was no significant difference in age, parity, and body mass index between the study groups. Sixteen and 44 of the cases were severe and mild preeclampsia, respectively. There was no significant difference in PDW and MPV between the preeclamptic and control women. Both PC and PC to MPV ratios were significantly lower in the women with preeclampsia compared with the controls. There was no significant difference in the PC, PDW, MPV, and PC to MPV ratio when women with mild and severe preeclampsia were compared. Using receiver operating characteristic (ROC) curves, the PC cutoff was $248.0 \times 10^{3} / \mu \mathrm{L}$ for diagnosis of preeclampsia ( $P=0.019$; the area under the ROC curve was $62.4 \%$ ). Binary regression suggests that women with $\mathrm{PC}<248.010 \times 10^{3} / \mu \mathrm{L}$ were at higher risk of preeclampsia (odds ratio $=2.2$, $95 \%$ confidence interval $=1.08-4.6, P=0.03$ ). The PC/MPV cutoff was 31.2 for diagnosis of preeclampsia $(P=0.035$, the area under the ROC curve was $62.2 \%$ ).

Conclusion: $\mathrm{PC}<248.010 \times 10^{3} / \mu \mathrm{L}$ and $\mathrm{PC}$ to MPV ratio 31.2 are valid predictors of preeclampsia.

Keywords: preeclampsia, platelets, PDW, mean platelet volume

\section{Background}

Preeclampsia is one of the major health problems during pregnancy. It complicates $3 \%-8 \%$ of pregnancies and causes marked increase in perinatal, maternal morbidity, and mortality. ${ }^{1-4}$ Although the exact pathophysiology of preeclampsia is not completely understood, certain factors have been attributed to it, which include deficient trophoblastic invasion of the maternal vascular bed with subsequent reduction of placental blood flow. ${ }^{5,6}$ Placental under perfusion initiates widespread systemic, maternal endothelial dysfunction, and increased vascular permeability. ${ }^{7}$ Coagulation system is activated by the contact of platelets with the injured endothelium leading to increase in consumption as well as bone marrow production of platelets. ${ }^{8}$ Various indices are used to measure platelet functions, for example, the platelet count (PC), mean platelet volume (MPV), the PC to MPV ratio, and platelet distribution width (PDW); PDW measures platelet
Correspondence: Ishag Adam Department of Obstetrics and Gynaecology, College of Medicine, Qassim University, PO Box 6655, Buriadah 51452, Kingdom of Saudi Arabia Tel +966537644287 Email ishagadam@hotmail.com 
size distribution. ${ }^{9}$ The utility of different platelets indices as predictors of preeclampsia has been studied previously; ${ }^{10-21}$ however, reports in this regard are controversial. The current study was conducted to evaluate platelets indices in women with preeclampsia.

\section{Methods}

A retrospective case-control study was conducted at Maternity and Children's Hospital, Buraidah, Kingdom of Saudi Arabia (KSA) during the period of February-July 2016. Maternity and Children's Hospital is a tertiary care center for the Qassim region. Cases were women with preeclampsia, which was defined as "occurrence of hypertension (systolic blood pressure $\geq 140 \mathrm{mmHg}$ or diastolic blood pressure $\geq 90$ $\mathrm{mmHg}$ ) in the second half of pregnancy (after 20 weeks of gestation) and proteinuria (presence of $300 \mathrm{mg}$ or more of protein in $24 \mathrm{~h}$ urine sample or $\geq 2+$ on dipstick)". ${ }^{22}$ Preeclampsia cases were considered mild or severe according to the diastolic blood pressure of $<110$ or $\geq 110 \mathrm{mmHg}$, respectively. ${ }^{23}$ Healthy pregnant women attended for antenatal care were taken as controls. Women with thyroid disease, hypertension, renal disease, diabetes mellitus, and liver diseases were excluded from the study groups.

The medical records of both cases and controls were reviewed for obstetrics history (age, parity, and gestational age). Data were collected using predesigned questionnaire. Maternal weight and height were recorded, and body mass index (BMI) was calculated as $\mathrm{kg} / \mathrm{m}^{2}$. Data of maternal hemogram taken at presentation were recorded. The hemogram included hemoglobin level, white blood cell (WBC) count, and platelet indices, namely PC, MPV, PDW, and PC to MPV ratio. The hemogram was performed using an automated hematology analyzer (Sysmex XN-9000; Sysmex Corporation, Hyogo, Japan).

A total sample size of 60 participants in each arm of the study groups was recorded to investigate the mean difference of the PC and MPV that would provide $80 \%$ power to detect a $5 \%$ difference at $\alpha=0.05$, with an assumption that complete data might not be available for $10 \%$ of participants.

\section{Ethics}

This study was approved by Regional Research Ethical Committee, Ministry of Health, Qassim, KSA who deemed written consent was not required due to the retrospective nature of the study.

\section{Statistics}

SPSS for Windows (version 20.0) was used for the data analyses. Continuous variables were checked for normality and their differences were compared between the cases and the controls using Student's $t$-test and Mann-Whitney $U$-test, when the data were normally and abnormally distributed, respectively. Binary regression was conducted, where preeclampsia was the dependent variable and medical, obstetrics, and platelets indices were the independent variable. Diagnostic screening tests were used to determine the diagnostic cutoffs of various parameters (based on test sensitivity and specificity) using receiver operating characteristic (ROC) curve. $P<0.05$ was considered statistically significant.

\section{Results}

While there was no significant difference in the basic characteristics (age, parity, and BMI) between the two study groups (60 women in each arm), gestational age was significantly lower in women with preeclampsia (Table 1). Sixteen and 44 of the cases were suffering from severe and mild preeclampsia, respectively. There was no case with HELLP syndrome.

There was no significant difference in WBC, hematocrit (HCT), red cell distribution width (RDW), PDW, and MPV between the two groups. Both PC and PC to MPV ratio values were significantly lower in the cases compared with the controls (Table 2).

Table I Characteristics of the cases and controls

\begin{tabular}{llll}
\hline Variable & Cases $(\mathbf{n = 6 0 )}$ & Controls $(\mathbf{n}=60)$ & P-value \\
\hline Mean (SD) & & & \\
Age, years & $30.6(6.0)$ & $30.01(6.2)$ & 0.504 \\
$\begin{array}{l}\text { Parity } \\
\text { Gestational age, }\end{array}$ & $2.3(1.8)$ & $2.6(1.4)$ & 0.521 \\
$\begin{array}{l}\text { weeks } \\
\text { Body mass index, }\end{array}$ & $31.8(4.3)$ & $32.9(4.0)$ & 0.001 \\
$\mathrm{~kg} / \mathrm{m}^{2}$ & & $29.7(6.1)$ & 0.833 \\
\hline
\end{tabular}

Abbreviation: SD, standard deviation.

Table 2 Median (interquartile range) of hematological values in preeclamptic and control women

\begin{tabular}{|c|c|c|c|}
\hline Variable & $\begin{array}{l}\text { Cases } \\
(n=60)\end{array}$ & $\begin{array}{l}\text { Controls } \\
(n=60)\end{array}$ & $P$-value \\
\hline White blood cells, $\times 10^{3} / \mu \mathrm{L}$ & $\begin{array}{l}8.1 \\
(6.7-9.9)\end{array}$ & $\begin{array}{l}7.9 \\
(5.8-9.9)\end{array}$ & 0.319 \\
\hline Hematocrit, \% & $\begin{array}{l}35.4 \\
(33.32-37.32)\end{array}$ & $\begin{array}{l}34.3 \\
(32.7-36.3)\end{array}$ & $0.347 \mid$ \\
\hline Red cell distribution width, \% & $\begin{array}{l}14.5 \\
(13.4-17.2)\end{array}$ & $\begin{array}{l}14.1 \\
(13.4-15.0)\end{array}$ & 0.172 \\
\hline Platelets count, $\times 10^{3} / \mu \mathrm{L}$ & $\begin{array}{l}236.5 \\
(176.0-278.25)\end{array}$ & $\begin{array}{l}259.0 \\
(215.7-322.7)\end{array}$ & 0.019 \\
\hline Mean platelet volume, $\mathrm{fL}$ & $\begin{array}{l}10.0 \\
(9.3-10.8)\end{array}$ & $\begin{array}{l}10.1 \\
(9.4-10.8)\end{array}$ & 0.799 \\
\hline Platelet distribution width, \% & $\begin{array}{l}12.7 \\
(I 1.4-15.8)\end{array}$ & $\begin{array}{l}13.2 \\
(11.4-14.9)\end{array}$ & 0.877 \\
\hline $\begin{array}{l}\text { Platelets count/mean platelet } \\
\text { volume }\end{array}$ & $\begin{array}{l}22.2 \\
(16.8-29.7)\end{array}$ & $\begin{array}{l}26.1 \\
(20.5-32.0)\end{array}$ & 0.035 \\
\hline
\end{tabular}


Table 3 Median (interquartile range) of hematological values in the women with mild and severe preeclampsia

\begin{tabular}{|c|c|c|c|}
\hline Variable & $\begin{array}{l}\text { Mild } \\
\text { preeclampsia } \\
(n=16)\end{array}$ & $\begin{array}{l}\text { Severe } \\
\text { preeclampsia } \\
(n=44)\end{array}$ & $P$-value \\
\hline $\begin{array}{l}\text { White blood cells, } \times \\
10^{3} / \mu \mathrm{L}\end{array}$ & $\begin{array}{l}8.2 \\
(6.0-9.5)\end{array}$ & $\begin{array}{l}8.1 \\
(6.7-10.2)\end{array}$ & 0.519 \\
\hline Hematocrit, \% & $\begin{array}{l}35.7 \\
(33.7-37.1)\end{array}$ & $\begin{array}{l}35.1 \\
(33.0-37.3)\end{array}$ & 0.564 \\
\hline $\begin{array}{l}\text { Red cell distribution } \\
\text { width, \% }\end{array}$ & $\begin{array}{l}13.6 \\
(12.8-15.8)\end{array}$ & $\begin{array}{l}14.9 \\
(13.7-17.4)\end{array}$ & 0.069 \\
\hline $\begin{array}{l}\text { Platelet count, } \times \\
10^{3} / \mu \mathrm{L}\end{array}$ & $\begin{array}{l}249.0 \\
(185.2-277.7)\end{array}$ & $\begin{array}{l}219.0 \\
(164.7-286.5)\end{array}$ & 0.300 \\
\hline $\begin{array}{l}\text { Mean platelet } \\
\text { volume, } \mathrm{fL}\end{array}$ & $\begin{array}{l}10.1 \\
(9.3-10.6)\end{array}$ & $\begin{array}{l}9.9 \\
(9.3-11.4)\end{array}$ & 0.575 \\
\hline $\begin{array}{l}\text { Platelet distribution } \\
\text { width, \% }\end{array}$ & $\begin{array}{l}12.5 \\
(11.4-14.1)\end{array}$ & $\begin{array}{l}12.8 \\
(11.4-16.0)\end{array}$ & 0.688 \\
\hline $\begin{array}{l}\text { Platelet count/mean } \\
\text { platelet volume }\end{array}$ & $\begin{array}{l}24.2 \\
(18.7-29.0)\end{array}$ & $\begin{array}{l}20.6 \\
(15.4-30.1)\end{array}$ & 0.380 \\
\hline
\end{tabular}

WBC, HCT, RDW, PC, PDW, MPV, and PC to MPV ratio were not significantly different when mild and severe preeclampsia women were compared (Table 3 ).

ROC curves were used to derive cutoffs for $\mathrm{PC}$ and the PC/MPV ratio. The PC cutoff was $248.0 \times 10^{3} / \mu \mathrm{L}$ for diagnosis of preeclampsia $(P=0.19)$. The area under the ROC curve was $62.4 \%$ (standard error $=5.1 \%$ ), which suggest poor predictability.

Based on binary regression analysis, women with PC $<248.010 \times 10^{3} / \mu \mathrm{L}$ were at higher risk to have preeclampsia (odds ratio $=2.2,95 \%$ confidence interval $=1.08-4.6$, $P=0.03)$. The PC/MPV cutoff was 31.2 for diagnosis of preeclampsia $(P=0.035)$. The area under the ROC curve was $62.2 \%$, and the standard error was $5.2 \%$ (Figure 1).

\section{Discussion}

The current study demonstrated significantly lower PC and PC to MPV ratio in patients with preeclampsia compared with the normal controls but failed to show similar trend when MPV and PDW were evaluated in the same study groups. Recently, Doğan et a $1^{14}$ observed significantly lower PC and PC/MPV in preeclamptic women compared with the controls. The same study documented significantly higher MPV in preeclamptic women than the control group. Likewise, Freitas et al, ${ }^{12}$ reported lower PC in women with preeclampsia.

There was no significant difference in PDW in the current study. This goes with the previous findings, where Doğan et al ${ }^{14}$ found no significant difference in PDW among women with severe preeclampsia, mild preeclampsia, and healthy controls. Nonetheless, a significantly higher level of PDW has recently been observed among women with preeclampsia. ${ }^{12,17,24}$

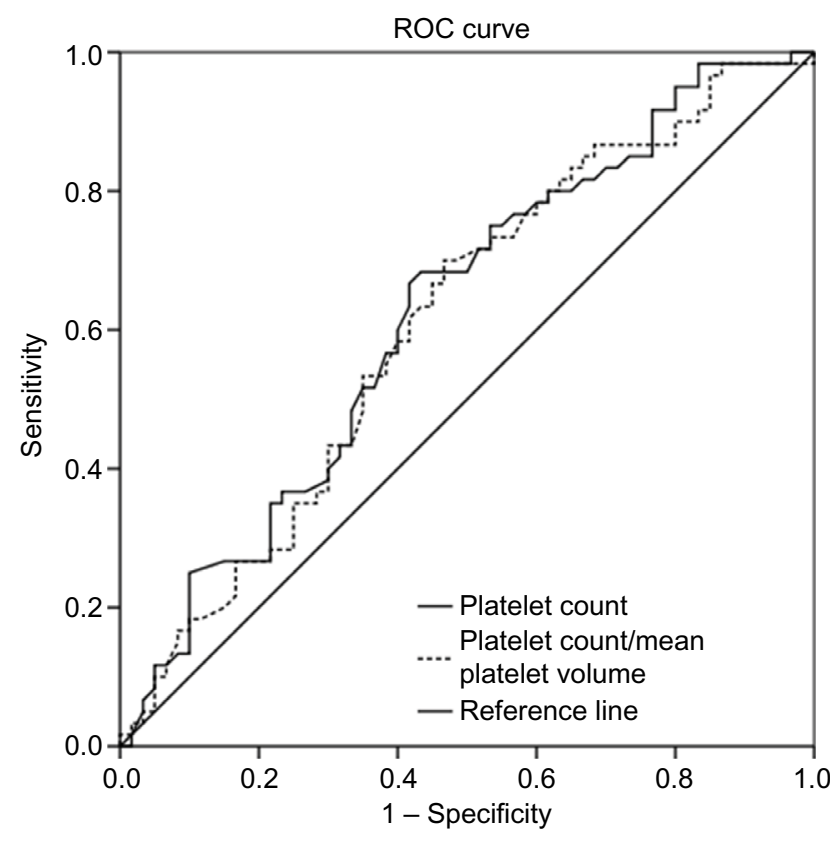

Figure I ROC curve for platelets, platelet count, and mean platelet volume ratio. Note: Diagonal segments are produced by ties.

Abbreviation: ROC, receiver operating characteristic.

Although, the current study showed no difference in the MPV between the cases and the controls, the utility of MPV in predicting preeclampsia has been shown in several studies. ${ }^{12,14-16,18-20}$ It is worth to mention that Yavuzcan et $\mathrm{al}^{21}$ observed no significant difference in the MPV between women with severe preeclampsia, healthy pregnant women, and healthy non-pregnant women. It is noteworthy that some researchers failed to confirm PC and MPV as predictors of preeclampsia, ${ }^{25,26}$ probably because of the differences in the methods and/or equipment used to obtain hemogram.

Contact of platelets with the injured endothelium activates the coagulation system, which can increase both consumption and bone marrow production of platelets. Enhanced thrombopoiesis produces younger platelets, which are larger (increased MPV) than older platelets, and they are metabolically and enzymatically more active. ${ }^{8}$

Aside from platelet parameters, there are several biomarkers of preeclampsia including soluble endoglin (sEng) or soluble fms-like tyrosine kinase-1 (sFlt-1). ${ }^{27}$ One limitation of this study is the lack of a comparative analysis between platelet parameters and sEng/sFlt-1. However, platelet parameters are simple laboratory markers and easy to check during antenatal care.

\section{Conclusion}

The current study suggests that PC and the PC/MPV ratio are useful in risk evaluation of preeclampsia. Large scale 
prospective studies are needed from early pregnancy to reach a definitive conclusion.

\section{Acknowledgment}

The study was supported by the Deanship of Scientific Research, Qassim University, KSA, grant number \# 3195.

\section{Disclosure}

The authors report no conflicts of interest in this work.

\section{References}

1 Adam GK, Bakheit KH, Adam I. Maternal and perinatal outcomes of eclampsia in Gadarif Hospital, Sudan. J Obs Gynaecol. 2009; 29(7):619-620.

2 Redman Christopher W, Sargent Ian L. Latest advances in understanding preeclampsia. Science. 2005;308(5728):1592-1594.

3 Walker JJ. Pre-eclampsia. Lancet (London, England). 2000;356(9237): $1260-1265$.

4 Anderson UD, Olsson MG, Kristensen KH, Åkerström B, Hansson SR. Review: biochemical markers to predict preeclampsia. Placenta. 2012;33 Suppl:S42-S47.

5 Burton GJ, Woods AW, Jauniaux E, Kingdom JCP. Rheological and physiological consequences of conversion of the maternal spiral arteries for uteroplacental blood flow during human pregnancy. Placenta. 2009;30(6):473-482.

6 Burton GJ, Charnock-Jones DS, Jauniaux E. Regulation of vascular growth and function in the human placenta. Reproduction. 2009; 138(6):895-902.

7 Maynard SE, Karumanchi SA. Angiogenic factors and preeclampsia. Semin Nephrol. 2011;31(1):33-46.

8 Juan P, Stefano G, Antonella S, Albana C. Platelets in pregnancy. J Prenat Med. 2011;5(4):90-92.

9 Tzur T, Sheiner E. Is there an association between platelet count during the first trimester and preeclampsia or other obstetric complications later in pregnancy? Hypertens Pregnancy. 2013;32(1):74-82.

10 Altınbas S, Toğrul C, Orhan A, Yücel M, Danısman N. Increased MPV is not a significant predictor for preeclampsia during pregnancy. J Clin Lab Anal. 2012;26(5):403-406.

11 Dundar O, Yoruk P, Tutuncu L, et al. Longitudinal study of platelet size changes in gestation and predictive power of elevated MPV in development of pre-eclampsia. Prenat Diagn. 2008;28(11):1052-1056.

12 Freitas LG, Alpoim PN, Komatsuzaki F, Carvalho Md, Dusse LM. Preeclampsia: are platelet count and indices useful for its prognostic? Hematology. 2013;18(6):360-364.
13 Kashanian M, Hajjaran M, Khatami E, Sheikhansari N. Evaluation of the value of the first and third trimester maternal mean platelet volume (MPV) for prediction of pre-eclampsia. Pregnancy Hypertens. 2013;3(4): 222-226.

14 Doğan K, Guraslan H, Senturk MB, Helvacioglu C, İdil S, Ekin M. Can platelet count and platelet indices predict the risk and the prognosis of preeclampsia? Hypertens Pregnancy. 2015;34(4):434-442.

15 Han L, Liu X, Li H, et al. Blood coagulation parameters and platelet indices: changes in normal and preeclamptic pregnancies and predictive values for preeclampsia. PLoS One. 2014;9(12):e114488.

16 Kanat-Pektas M, Yesildager U, Tuncer N, Arioz DT, Nadirgil-Koken G, Yilmazer M. Could mean platelet volume in late first trimester of pregnancy predict intrauterine growth restriction and pre-eclampsia? $J$ Obstet Gynaecol Res. 2014;40(7):1840-1845.

17 Karateke Atilla, Kurt Raziye Keskin, Baloğlu Ali. Relation of platelet distribution width (PDW) and platelet crit (PCT) to preeclampsia. Ginekol Pol. 2015;86(5):372-375.

18 Moraes D, Munhoz TP, Pinheiro da Costa BE, et al. Immature platelet fraction in hypertensive pregnancy. Platelets. 2016;27(4):333-337.

19 Özdemirci Ş, Başer E, Kasapoğlu T, Karahanoğlu E, Kahyaoglu I, Yalvaç $\mathrm{S}$, Tapısız Ö. Predictivity of mean platelet volume in severe preeclamptic women. Hypertens Pregnancy. Epub 2016 Jun 17:1-9.

20 Vilchez G, Londra L, Hoyos LR, Sokol R, Bahado-Singh R. Intrapartum mean platelet volume is not a useful predictor of new-onset delayed postpartum pre-eclampsia. Int J Gynaecol Obstet. 2015;131(1):59-62.

21 Yavuzcan A, Cağlar M, Ustün Y, et al. Mean platelet volume, neutrophillymphocyte ratio and platelet-lymphocyte ratio in severe preeclampsia. Ginekol Pol. 2014;85(3):197-203.

22 ACOG technical bulletin. Hypertension in pregnancy. Number $219-$ January 1996 (replaces no. 91, February 1986). Committee on Technical Bulletins of the American College of Obstetricians and Gynecologists. Int J Gynaecol Obstet. 1996;53(2):175-183.

23 ACOG Committee on Obstetric Practice. ACOG practice bulletin. Diagnosis and management of preeclampsia and eclampsia. Number 33, January 2002. American College of Obstetricians and Gynecologists. Int J Gynaecol Obstet. 2002;77(1):67-75.

24 Yang SW, Cho SH, Kwon HS, Sohn IS, Hwang HS. Significance of the platelet distribution width as a severity marker for the development of preeclampsia. Eur J Obstet Gynecol Reprod Biol. 2014;175:107-111.

25 Makuyana D, Mahomed K, Shukusho FD, Majoko F. Liver and kidney function tests in normal and pre-eclamptic gestation - a comparison with non-gestational reference values. Cent Afr J Med. 2002;48(5-6):55-59.

26 Ceyhan T, Beyan C, Başer I, Kaptan K, Güngör S, Ifran A. The effect of pre-eclampsia on complete blood count, platelet count and mean platelet volume. Ann Hematol. 2006;85(5):320-322.

$27 \mathrm{He} \mathrm{Y,} \mathrm{Xu} \mathrm{B,} \mathrm{Song} \mathrm{D,} \mathrm{Yu} \mathrm{F,} \mathrm{Chen} \mathrm{Q,} \mathrm{Zhao} \mathrm{M.} \mathrm{Correlations} \mathrm{between}$ complement system's activation factors and anti-angiogenesis factors in plasma of patients with early/late-onset severe preeclampsia. Hypertens Pregnancy. Epub 2016 Jun 17:1-11.
Vascular Health and Risk Management

\section{Publish your work in this journal}

Vascular Health and Risk Management is an international, peerreviewed journal of therapeutics and risk management, focusing on concise rapid reporting of clinical studies on the processes involved in the maintenance of vascular health; the monitoring, prevention and treatment of vascular disease and its sequelae; and the involvement of

\section{Dovepress}

metabolic disorders, particularly diabetes. This journal is indexed on PubMed Central and MedLine. The manuscript management system is completely online and includes a very quick and fair peer-review system, which is all easy to use. Visit http://www.dovepress.com/ testimonials.php to read real quotes from published authors. 